\title{
Recommendations for the next generation of global freshwater biological monitoring tools
}

Jackson, M.C. ${ }^{1,2}$, Weyl, O.L.F. ${ }^{3}$, Altermatt, F. ${ }^{4,5}$, Durance, I. ${ }^{6}$, Friberg, N. ${ }^{7,8}$, Dumbrell, A.J. ${ }^{9}$, Piggott, J.J. ${ }^{10,11}$, Tiegs, S.D. ${ }^{12}$, Tockner, K. ${ }^{13}$, Krug, C.B. ${ }^{14}$, Leadley, P.W. ${ }^{14}$ and Woodward, $\mathrm{G}^{2}$

1. Department of Zoology and Entomology, University of Pretoria, Hatfield, Gauteng, South Africa

2. Department of Life Sciences, Imperial College London, Silwood Park Campus, Buckhurst Road, Ascot, Berkshire SL5 7PY, UK

3. South African Institute for Aquatic Biodiversity, Grahamstown, Eastern Cape, South Africa

4. Eawag, Swiss Federal Institute of Aquatic Science and Technology, Department of Aquatic Ecology, Überlandstrasse 133, CH-8600 Dübendorf, Switzerland

5. Department of Evolutionary Biology and Environmental Studies, University of Zurich, Winterthurerstr. 190, CH-8057 Zürich, Switzerland

6. Cardiff Water Research Institute, School of Biosciences, Cardiff University, Cardiff CF10 3TL, UK

7. Norwegian Institute for Water Research (NIVA), Gaustadalleen 21, Oslo N-0349, Norway

8. water@leeds, School of Geography, University of Leeds, Leeds LS2 9JT, United Kingdom

9. School of Biological Sciences, University of Essex, Wivenhoe Park, Colchester CO4 3SQ, UK

10. Department of Zoology, University of Otago, Dunedin 9054, New Zealand

11. Center for Ecological Research, Kyoto University, Otsu, Japan

12. Department of Biological Sciences, Oakland University, Rochester, Michigan 483094401 USA

13. Leibniz- Institute of Freshwater Ecology and Inland Fisheries, 12587 Berlin, and Freie Universität Berlin, Germany

14. Laboratoire ESE, Université Paris-Sud, UMR 8079 CNRS, UOS, AgroParisTech, 91405 Orsay, France 


\section{Summary}

Biological monitoring has a long history in freshwaters, where much of the pioneering work in this field was developed over a hundred years ago - but few of the traditional monitoring tools provide the global perspective on biodiversity loss and its consequences for ecosystem functioning that are now needed. Rather than forcing existing monitoring paradigms to respond to questions they were never originally designed to address, we need to take a step back and assess the prospects for novel approaches that could be developed and adopted in the future. To resolve some of the issues with indicators currently used to inform policymakers, we highlight new biological monitoring tools that are being used, or could be developed in the near future, which (1) consider less-studied taxonomic groups; (2) are standardised across regions to allow global comparisons, and (3) measure change over multiple time points. The new tools we suggest make use of some of the key technological and logistical advances seen in recent years - including remote sensing, molecular tools, and local-to-global citizen science networks. We recommend that these new indicators should be considered in future assessments of freshwater ecosystem health and contribute

to the evidence base for global to regional (and national) assessments of biodiversity and ecosystem services: for example, within the emerging framework of the Intergovernmental Platform on Biodiversity and Ecosystem Services.

\section{Keywords}

Global biomonitoring; IPBES; Next-generation sequencing; eDNA; Remote sensing; Multiple stressors; Ecological networks 


\section{Introduction}

The unprecedented rate of decline in global biodiversity has been linked to anthropogenic stressors including habitat loss, pollution, the changing climate and species invasions (Global Biodiversity Outlook 4 2014; WWF 2014). These stressors are expected to become both more widespread and more intense in the future as the growing human population imposes an ever stronger footprint on natural ecosystems, and temperatures continue to rise (Bellard et al. 2012; Tittensor et al. 2014). In recent years, there has been a call for the use of bioindicators by policymakers to monitor and predict the impacts of these multiple environmental stressors on ecosystems (Pereira et al. 2013; Hoffmann et al. 2014). However, current indicators for freshwater systems simply quantify drivers of change, such as temperature or the number of non-native species, and we urgently need new indicators of modifications in ecological state (i.e. loss of biodiversity and associated ecosystem functioning). In particular, these need to enable us to link cause to effect, and structure to function across multiple levels of organisation - from genes to entire ecosystems.

Decision-makers need monitoring that is simple, effective, and which allows them to measure the efficiency of interventions or management actions that were undertaken in response to environmental impacts (Pereira et al. 2013). This has resulted in the recent establishment of collaborative platforms, such as the Intergovernmental Platform on Biodiversity and Ecosystem Services (IPBES) to assess the state of biodiversity and the ecosystem services it provides. However, many current indicators, such as extinction risk, are often based on secondary information of typically rather abstract, derived measures or proxies, rather than on primary data. Moreover, the predictive power of freshwater indicators is often constrained by measures of biodiversity loss that are taxonomically and trophically biased towards easily sampled and readily identifiable taxa (e.g., fishes and macroinvertbrates), have a patchy global coverage and/or are incomparable between 
regions due to the high degree of local contingency in their historical development (Revenga et al. 2005; Nicholson et al. 2012). This may seem surprising because freshwater systems are home to $\sim 10 \%$ of the Earths diversity despite only covering $<1 \%$ of total surface area (Dudgeon et al. 2006; Strayer and Dudgeon 2010), and the earliest pioneering work in biomonitoring was initiated in these systems well over a century ago (Friberg et al 2011). Endemism is also unusually high: for example, it is close to $100 \%$ in the diverse fish communities of Lake Malawi ( 1000 species) and Lake Victoria ( 500 species; Salzburger et al 2005). This has resulted in a focus on uniqueness, rarity, and species richness, rather than aiming to develop globally applicable monitoring schemes and those focused on ecosystem properties. Freshwater ecosystems are also increasingly recognised for the essential 'goods and services' that they provide, such as flood mitigation, fish protein, and in particular, drinking water, yet many of the underlying links between biodiversity and the delivery of these outputs are still poorly understood (Durance et al 2015; Raffaelli et al. 2014). Even the link between the precursors to service delivery - ecosystem functioning, and biodiversity is still poorly characterised, especially in terms of how its relationship to biodiversity is shaped by environmental conditions (but see Perkins et al 2015).

The relatively few larger-scale surveys that have been conducted in freshwater systems show that diversity is declining much faster than in terrestrial and marine realms (Stayer and Dudgeon 2010), underlining how vulnerable they are to environmental change. For example, The Living Planet report estimated alarming average population declines of $76 \%$ between 1970 and 2010 in freshwater species (WWF 2014). However, this indicator only focuses on vertebrates and therefore does not consider some of the most diverse groups in freshwaters (e.g. invertebrates, microbes, parasites and plants), highlighting the need for new monitoring approaches which consider other important taxonomic groups. These surveys are also often patchy and scarce in both time and space and are therefore highly aggregated into coarse metrics at large scales: thus, there is a pressing need for new indicators that quantify 
biodiversity loss across wide spatial and temporal scales. A wide global coverage with multiple time points would allow policy makers to compare diversity change between regions, and identify drivers of diversity loss over time. However, some form of taxon-free or functional approach is likely to be is likely to be needed to circumvent some of the problems arising from biogeographical differences among functionally similar systems (Friger et al 2011), which is still largely non-existent beyond local to regional scales. Here we gauge the potential of some indicators which could meet some or all of these requirements, and which we argue should be urgently considered for adoption in future global monitoring programmes.

\section{Invertebrates as indicators of ecosystem state}

Invertebrates are one of the most diverse groups in freshwater ecosystems and are essential for the delivery of many ecosystem processes, such as decomposition (Chauvet et al 2016 THIS VOLUME), and they link plant primary production to higher trophic levels, such as fish and the ecosystem services they underpin. Despite this, indicators of macroinvertebrate abundance or diversity are rarely considered by policymakers beyond local to national scales. Their many shortcomings have been reviewed extensively elsewhere in recent years (Friberg et al. 2011; Baird and Hajibabaei 2012; Gray et al. 2014), so we will not revisit these issues in any great detail here beyond a cursory overview.

One approach to providing regional and global perspectives would be to develop a uniform measure of change in invertebrate biodiversity (and potentially any other grouping of taxa) by comparing disturbed sites to relatively pristine sites as a baseline (e.g. Scholes and Biggs 2005). There are already many existing regional indicators of river health based on macroinvertebrate community composition. For instance, the South African Scoring System 
(SASS) assigns invertebrate families a sensitivity score (according to the water quality conditions they are known to tolerate) which is then used to calculate a score of overall river health based on the community assemblage (Dickens et al. 2002). Similar indicators, which are founded on typologies or comparisons to reference conditions, include RIVPACS (River Invertebrate Prediction and Classification System; Wright et al. 1998) in the United Kingdom, PERLA in the Czech Republic (Kokes et al. 2006), AUSRIVAS (Australian River Assessment System; Smith et al. 1999) in Australia, MCl (Macroinvertebrates Community Index; Stark, 1985) in New Zealand, and the IBCH index in Switzerland (Altermatt et al. 2013, Stucki 2010). Differences between each approach make it difficult to compare absolute biodiversity; however, it is possible to use the data to determine important trends. Since the scores of river health are typically based on natural reference conditions of relatively unimpacted invertebrate diversity, the data will indicate if a location has experienced biodiversity change. This information can then be synthesised at a larger scale to make more meaningful comparisons of macroinvertebrate community health. Such indices, however, are not designed to disentangle the impacts of multiple stressors (Box 1), and most have focused on either a single stressor such as organic pollution or acidification, or provide "blackbox" measures of overall stress of an undefined and unknown suite of stressors.

Box 1 - Multiple indicators for multiple stressors: While ecological indicators provide a useful tool to track and compare ecosystem states or trends, disentangling indicator drivers can be particularly challenging due to multiple interacting stressors. Freshwater indicator responses frequently demonstrate complex synergistic, antagonistic or reversal of effects to multiple stressors that cannot be predicted from knowledge of their single effects acting in isolation (Jackson et al. 2016). Additionally, some response indicators which have traditionally been used to assess ecosystem state may become increasingly unreliable in the future, e.g., under a warming climate (Piggott et al. 2015a). Coupled with this challenge are the shifting baselines and emergent novel ecosystem properties that the multiple drivers of 
global change may manifest. Responses to multiple stressors are also highly context dependent, with the same taxonomic group often responding to the same set of stressors in different ways in different places (Jackson et al. 2016).

Integrative indices may be less susceptible to multiple-stressor effects that dampen and diffuse effects at lower levels of organisation (Crain et al. 2008); however evidence for this is inconclusive. A possible solution might involve the use of multiple indicators in combination to help disentangle stressor effects when they are in opposite directions (i.e. one stressor causes diversity loss, and the other an increase; Piggott et al. 2015b). In this case, a complementary approach which employs both indicators of drivers of change (i.e. the number of non-native species and temperature) and indicators of ecosystem state (i.e. diversity measures) could be used to disaggregate stressor effects. A similar problem occurs when different taxonomic groups respond in different ways (i.e. fish and plants experience a decline and increase in diversity, respectively).

Indicators of whole ecosystem change at the network level (e.g. food webs) will also be valuable when unravelling the multiple responses of ecosystems to multiple stressors. This approach will provide a whole ecosystem perspective which is consistent and comparable between regions (Gray et al. 2014; QUINTESSENCE Consortium 2016). Network metrics such as connectance (i.e. the number of food web links) will permit taxonomic free whole food web responses and, in some cases, the impacts of multiple stressors may only manifest at this level of organisation (O'Gorman et al. 2012; Gray et al. 2014). For example, a network approach was successfully employed to disentangle the roles of flood disturbance and urbanisation in structuring stream biodiversity in Italy (Calizza et al. 2015), and to quantify the impact of inorganic nutrients and organic matter on intertidal food web in Ireland (O'Gorman et al. 2012; Figure 1). At present though, these more holistic and information-rich approaches are still in the early stages of development as novel monitoring tools (e.g. Thompson et al 2016; Gray et al, THIS VOLUME) and still some way behind the other more 
measures we have highlighted here as approaches that could realistically be applied globally in the near-future.

Figure 1, Box 1: Conceptual figure showing an intertidal food web in its natural state (control food web) and affected by nutrient enrichment and organic matter supplements (multiple stressor food web) where the nodes and lines represent species and trophic links, respectively. The food web under the influence of multiple stressors supported larger and more generalist top predators, had higher connectance between species, and lower biodiversity. Taken from O'Gorman et al. (2012).

\section{Control food web}

Species richness: High

Connectance: Low

Food chain length: Low

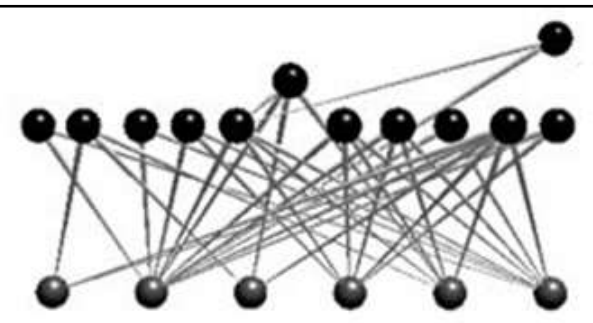

Multiple stressor food web

Species richness: Low

Connectance: High

Food chain length: High

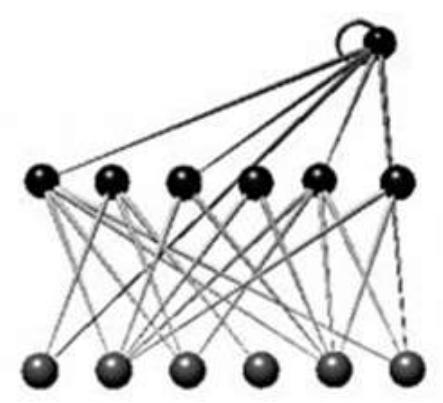

Citizen science groups are increasingly expanding the spatial and temporal coverage of invertebrate-based approaches. For instance, the Riverfly Partnership (http://www.riverflies.org/) in the United Kingdom is a network of citizen scientists who are trained in a simple invertebrate monitoring technique to classify river health (Box 2). MiniSASS (http://www.minisass.org/) in South Africa uses a similar approach and both have large and growing online data repositories (Box 2). We suggest that combining these river health indicators across a global scale with the aid of citizen science networks will increase 
our knowledge on the extent of biodiversity change in macroinvertebrate communities across the globe. There is increasing evidence that these ideas are being taken up at an accelerating rate, often from a combination of top-down and bottom-up grassroots coordination (Huddart et al 2016). The key challenge to overcome in the coming years is to find an effective means to maintain continuity and quality control in these largely self-organising and otherwise unregulated bodies (Follett and Strezov, 2015; Huddart et al 2016).

Box 2 - Citizen Science Networks: A citizen scientist is a volunteer who collects or processes data, usually with the backing of a scientist or research project. Ecological projects involving citizen scientists are growing (Silvertown et al. 2009) with the general public's mounting interest in protecting the environment. Two examples from the freshwater realm are miniSASS in South Africa and the Riverfly Partnership in the United Kingdom, both use simple macroinvertebrate monitoring to categorise river health (Figure 2). In South Africa, 462 sites are monitored by miniSASS volunteers and in the last assessment (data obtained in March 2016), 46\% were categorised as very poor, $12 \%$ as poor, $16 \%$ as fair, $17 \%$ as good and $9 \%$ as very good (Figure $2 a$ ). In the UK, The Riverfly Partnership uses a slightly different scoring technique (Huddart et al 2016), but we were able to use the information to assign comparable health categories (Figure 2). A total of 449 sites are monitored in the United Kingdom and in the last assessment (data obtained March 2016) 8\% were categorised as very poor, $31 \%$ as poor, $39 \%$ as fair, $20 \%$ as good and $2 \%$ as very good (Figure 2b). If such schemes could be expanded to other countries, the data could be added to a global database of invertebrate community health and, therefore, overall river health. 
Figure 2, Box 2: Locations of citizen science monitoring sites in (a) South Africa (miniSASS) and (b) United Kingdom (Riverfly Partnership). Sites are categorised as very poor (filled triangle), poor (filled circle), fair (grey circle), good (open circle) or very good (open triangle) health (and therefore from low to high invertebrate diversity)
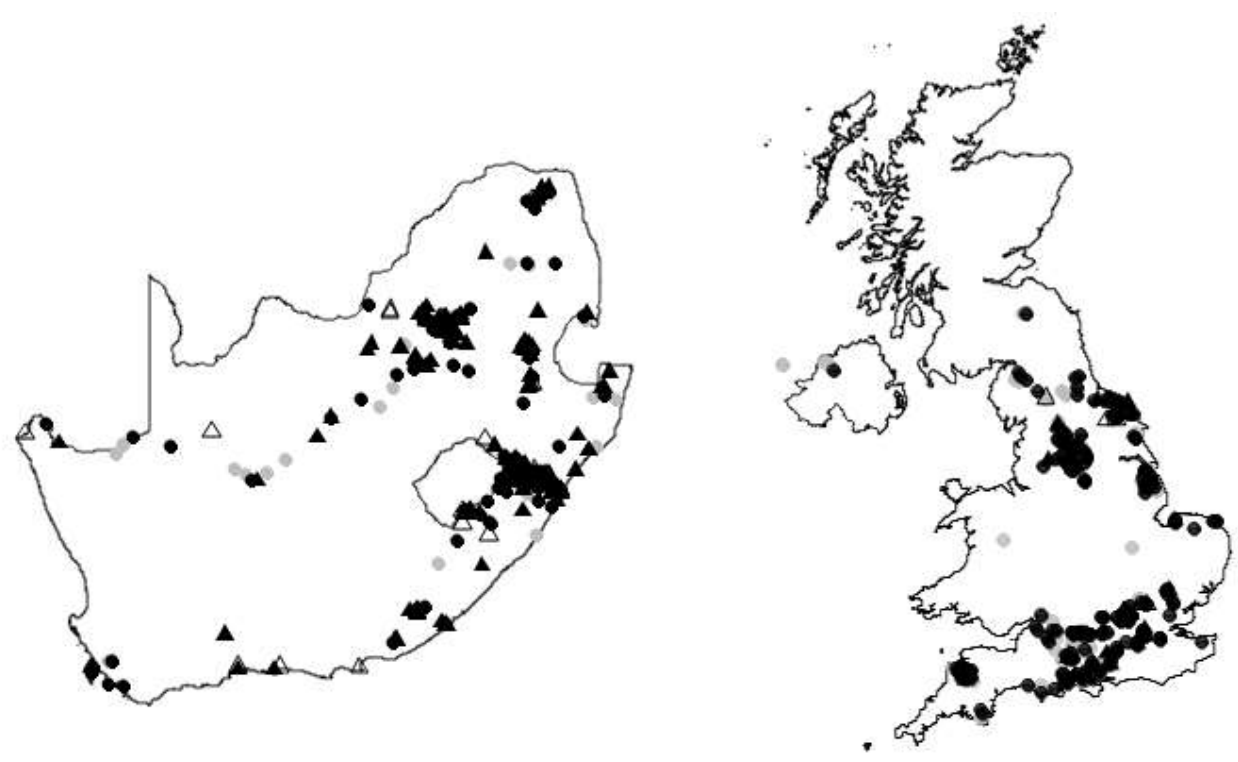

The use of invertebrate species functional traits (i.e. inherited characteristics of species, such as the presence of external gills) to monitor diversity change has recently gathered momentum because it allows comparison across spatial and temporal scales, avoiding problems associated with biogeographical uniqueness and endemism (Statzner et al. 1997; Mcgill et al. 2006; Beche et al. 2006; Costello et al. 2015). They are also rooted in ecological and evolutionary concepts related to ecological equivalence and convergent evolution, as well as redundancy, which resonate with the body of theory built up around research into the resilience of biodiversity-ecosystem functioning relationships under environmental change. Trait-based indicators can thus be standardised across areas with different species diversity to predict changes in ecosystem functioning, as well as providing complementary and unique information that goes beyond simple species richness-based indices (Seymour et al. 2016). For instance, the morphological traits of some invertebrate species allow the consumption of leaf litter at different rates (Chauvet el al 2016 THIS VOLUME). Therefore, leaf-litter decomposition, a key ecosystem function, depends on the diversity of this trait within the 
ecosystem (Crowl et al. 2001; Chauvet el al. 2016 THIS VOLUME). Additionally, because traits relate directly to environmental characteristics such as temperature and water flow, they provide a good mechanistic understanding of how environmental change influences biotic communities, and are therefore a step towards diagnosing cause and effect (Doledec et al. 1999; Rabeni et al. 2005).

Numerous studies have shown that macroinvertebrate trait metrics can be sensitive to human stressors (Doledec et al. 1999; Charvet et al. 2000; Menezes et al. 2010; Boersma et al. 2016), but there is still a need to gather additional evidence concerning the overall effectiveness of a species trait approach at global scales (Demars et al. 2012). Trait-based indicators are also still subject to many of the same constraints as taxonomic-based macroinvertebrates indices, in that both need to be clearly linked to the stressor in question, and also to provide sufficient accuracy and precision to detect changing conditions. However, there is undoubtedly real scope for using species traits as global indicators of biodiversity change because they are spatially robust across biogeographically distinct regions, but additional research is needed to make these indicators operative at such scales. In particular, careful selection of traits would allow differentiation between response to environmental variability (response traits) and effects on ecosystem functioning (effect traits) (Sterk et al 2013).

\section{Decomposition-based indicators}

Despite not always relating directly to biodiversity, an alternative to an invertebrate based approach is the direct measurement of the important ecosystem services that invertebrates and micro-organisms perform. For instance, decomposition, the processing of organicmatter, is a universal ecosystem process with many attributes that make it an obvious and 
logical choice for use as an indicator of human impacts at local to global scales (Chauvet et al 2016 THIS VOLUME). Foremost among these is its sensitivity to some of the most pressing threats in freshwaters, including chemical pollution, warming and land-use change (e.g., Hldayz et al 2011; Woodward et al 2012; Perkins et al 2015; Griffiths and Tiegs, 2016). Additionally, given the vital significance of decomposition to the functioning of freshwater ecosystems around the globe (it underpins the bulk of the trophic basis of production in many systems) a large body of literature has been devoted to its study. This body of work can now be used to conduct formal large scale analyses or meta-analyses to interpret data in the context of a wide range of human impacts (Chauvet et al 2016 THIS VOLUME). Most decomposition assays are 'taxon-free' and therefore do not require any taxonomic expertise; in most cases they simply measure mass loss (or an associated proxy) of a substrate (usually leaf-litter) over time. They are also simple and inexpensive, and some can be highly standardised. For example, cotton strip assays (CSAs) provide an easily repeatable way to quantify organic-matter decomposition by microbes in aquatic habitats. Unlike most traditional decomposition assays that rely on the quantification of mass loss of terrestrial leaf-litter, the CSA operates by determining the loss of tensile strength of standardized cotton fabric, a process that equates to the degradation of cellulose - an important source of carbon in its globally most abundant forms as a food resource, in many ecosystems (Tiegs et al. 2013). Given its pivotal role at the base of the food web, changes in the processing rates of cellulose decomposition provide a universal measure of one of the most common ecosystem processes on the planet, and one that is sensitve to environmental change (e.g. Jenkins et al 2013). Since this approach is comparable at any scale and simple to use (and therefore could also be deployed by citizen science networks), it has the potential to become one of the first bioindicators available to ecologists at a spatio-temporal resolution previously only known for physio-chemical indicators, such as temperature or water chemistry (Chauvet et al 2016 THIS VOLUME). 


\section{Fishery indicators: learning from the marine realm}

At the opposite end of aquatic food chains, indicators related to fisheries are widely used in the marine realm (e.g. Coll et al. 2015; http://www.indiseas.org/) although their inland counterparts are still surprisingly rarely considered by policymakers despite the importance of freshwater fisheries, especially in many developing countries (Brummett et al. 2013). This is exemplified by the Food and Agriculture Organisation of the United Nations (FAO; http://www.fao.org/fishery) fishery catch database, which found in 2008 alone that $>10$ million metric tonnes of fish were produced by freshwater fisheries (Brummett et al. 2013). These productivity data are freely available and, in marine ecosystems, are employed as useful indicators of both fishery health and overall ecosystem condition. Indicators for the Seas, a programme that evaluates effects of fishing on marine ecosystems, suggests using multiple fish-based indicators simultaneously, such as average fish size (which depends on the impact of harvests), the average trophic level of landed catch (i.e. catch composition), and total biomass of surveyed species (i.e total production; Coll et al. 2015) as a fundamental set of indicators. Analogous indicators can be derived from freshwater ecosystems, and where fishery yields are influenced by both human and environmental drivers, including harvesting, nutrient loading, climate and pollution; clear links can be established to these stressors that could be rolled out as a basic global bio-assessment scheme (Allan et al. 2005, Welcomme et al. 2010, Pauly and Froese 2012). Catch data allow for the assessment of not only changes in total landings, but also for changes in species composition, trophic level and abundance, which are all recognised as good indicators of the impacts of exploitation (Allan et al. 2005). Additionally, recent evidence suggests that yield is directly correlated with fish biodiversity (Brooks et al. 2016).

Inland fisheries catches are reported via the FAO for 156 countries (Garibaldi 2012, Bartley et al. 2015) and more disaggregated catch and effort data (e.g. number of fishers, boats and 
fishing gear) are also often available. However, data quality is variable and while some countries have a $>40$ year time series of catch and effort data (e.g. Malawi, Weyl et al. 2010), data are still lacking for others (Welcomme, 2011). Additionally, some lake systems are not fished, and in others there are considerable challenges regarding the accuracy of reported data (Welcomme et al. 2010; Garibaldi 2012; Bartley et al. 2015). The social and economic value of inland fisheries is gaining increased recognition (Welcomme et al. 2010; Brummett et al. 2013) and we contend that they have additional value as global indicators for ecosystem change, which could be adopted relatively quickly by building on the approaches already developed in marine systems.

\section{Molecular-based indicators}

Classic indicators of freshwater diversity focus only on a small subset of taxonomic groups embedded within the wider food web, such as fish. Furthermore, these indices are often not standardised across regions, so comparisons of ecological state are difficult. Trait-based approaches or measures of functional diversity provide one avenue to standardise indicator assessments. Alternatively, assessments based on molecular markers, particularly nucleic acids (DNA or RNA), have the potential to provide both taxonomic and functional data, across all three domains of life, and at a fraction of the cost and time associated with traditional approaches. Recent reductions in the cost and capacity of DNA sequencing technologies (i.e. Next Generation Sequencing; NGS), alongside more effective methods of extracting DNA from environmental samples and other novel DNA-based techniques (e.g. metabarcoding of pooled invertebrate samples), have highlighted the potential for these molecular methods to become a unifying and globally comparable indicator of freshwater diversity (Lodge et al. 2012; Bohmann et al. 2014; Mächler et al. 2016). 
Environmental DNA (eDNA) is ubiquitous in ecosystems, originating from organismal excretions and loose cells (including microbes), among many other sources. This ubiquity of eDNA, coupled with the assumption that all taxa produce it and that sampling methods can be standardised, has led to an emergent research field promoting eDNA as the solution for rapid, non-invasive monitoring of species from any environment (Bohmann et al. 2014). eDNA approaches typically focus on the isolation of free DNA directly from the environment followed by some form of taxon-specific quantification based around PCR amplification of the eDNA (e.g. for NGS community-level analysis, or to quantify specific populations via qPCR). Thus, these approaches are still intrinsically linked to providing taxonomic-based assessments of biodiversity, albeit at a range of taxonomic breadths decided by the practitioner. This link to taxonomy in itself is not a major problem, as eDNA approaches can be designed to simultaneously target the majority of major taxonomic or functional groups, moving freshwater monitoring away from a narrow focus around a few specific species (e.g. fish). This combined with the speed and ever decreasing cost of eDNA approaches makes them a very attractive monitoring option. Furthermore, by combining eDNA-based data targeting maximum taxonomic coverage with machine-learning based approaches, the ecological networks (e.g. food webs and/or species interaction networks) present in the system can be resolved (Vacher et al. 2016). Subsequently this information can generate a range of network properties (e.g. connectance, linkage strength; see Box 1) that can provide a universal set of measures for monitoring that do not require an a priori knowledge of the ecosystem or a specific composition of species to be present. A major advantage of these more holistic measures over traditional trait-based approaches is that they can take into account whole system properties and also indirect effects of species interactions - which often give rise to "ecological surprises" or hystereses, such as trophic cascades and regime shifts, in biomonitoring schemes. In essence, they represent a next step beyond autecological species traits to more synecological attributes that arise from those traits at the whole-system level (Gray et al 2014). 
Despite its huge potential and appeal, our current ability to detect eDNA within aquatic systems is still primarily a function of time from cellular release, as exposure to UV light and extracellular enzymatic activity from microbes cleaves eDNA into shorter fragments until it is impractical to investigate or is completely degraded (Rees et al. 2014). These constraints need to be far better charaterised and understood as part of the quality control process we now need to develop if the field is to mature sufficiently to deliver fully on its promise. Spatial limits to detection are determined by how far eDNA diffuses or actively travels before it is fully degraded, which can be over $10 \mathrm{~km}$ from its source within a few days or weeks (Deiner and Altermatt, 2014). Alternatively, these methodological constraints could be considered strengths depending on the context and scale of assessment in which eDNA approaches are deployed - especially for global monitoring that aims to use a relatively small number of widely dispersed spot measurements to characterise ecological systems over much larger scales. If monitoring is to move away from point measures of biodiversity to catchment-scale evaluations, then eDNA holds massive potential as it has the ability to integrate measure of biodiversity over large spatial, but short temporal, scales. Furthermore, if more precise predictions of eDNA sources are required (e.g. for fine scale evaluation of an organisms range), then it is feasible that DNA degradation rates from controlled sources may be used to evaluate how long eDNA persists within the environment. In turn this generates additional data for monitoring, as it provides information on UV penetration and microbial activity within aquatic systems, which could contribute towards a metric of aquatic ecosystem health and potentially of ecosystem services, such as water purification by microbes.

Arguably, one of the main strengths of nucleic acid (DNA or RNA) based approaches for monitoring is broad-scale evaluations of functionally important groups, notably microbes, via either non-targeted shotgun methods (i.e. NGS metagenomics and metatranscriptomics) or targeted approaches (NGS amplicon techniques or qPCR). Microbial communities underpin almost all ecosystem functions, and support the key biogeochemical processes and 
macronutrient cycles. In addition, microbial populations and the associated functional genes that regulate macronutrient cycling are reasonably well known (Nedwell et al. 2016 THIS VOLUME), and changes in these across environmental gradients are increasingly being characterised in the field (e.g. Lansdown et al. 2016). Yet despite the functional importance of these groups, and established NGS and qPCR approaches for quantifying them (e.g. Papaspyrou et al. 2014; Li et al. 2015; Lansdown et al. 2016; Thompson et al. 2016), they are still rarely included in monitoring of diversity change. Combining information on functionally important groups of microbes with eDNA based assessments of biodiversity could provide a new paradigm in monitoring, as it provides direct insights into the functional capacity and health of ecosystems. Furthermore, a non-targeted metagenomic approach will also capture microbial responses to novel energy sources used for their metabolism (e.g. organophosphates, hydrocarbons, lipids), providing a rapid indicator of potential pollution events. For example, a small spill of the organophosphate chlorpyrifos, which wiped out invertebrate life over a $15 \mathrm{~km}$ stretch of a UK river, triggered a greater than three orders of magnitude increase in the abundance of microbial populations containing the organophosphate hydrolase gene (opd; Thompson et al. 2016). In addition, collection of the samples required for all molecular approaches is straightforward and therefore there is potential for convergence with with citizen science approaches (Box 2) and global coverage is feasible.

\section{Indicators of change across space and time}

Macroinvertebrate, fishery, molecular-based and decomposition-based indicators all have the potential to be standardised across space and time, but current coverage is limited and, in many instances, data from developing countries are absent or estimated. There is, therefore, a need for indicators which already have a standardised methodology across a global scale and long time span. For instance, The Global Lake Ecological Observatory 
Network (GLEON; http://gleon.org/) has a worldwide network of data gathering buoys in lakes to document changes that occur in response to different stressors. Data collected include water temperature, dissolved oxygen and phytoplankton chlorophyll fluorescence. Similarly, International Rivers (www.internationalrivers.org/worldsrivers) has coverage of river health across 50 major river basins. Many indicators are associated with drivers of change (e.g. number of dams and percentage of non-native fish) but indicators of species richness are also available, although they are taxonomically biased with a focus on mammals and birds. These global observatories clearly offer potential for building on existing infrastructure or sampling programmes to incorporate some of the new measures advocated here, and at relatively minimal cost when compared with the creation of new projects from scratch (Nedwell et al. THIS ISSUE).

Remote sensing technology also has the advantage of offering global coverage data that can be standardised and repeatable over multiple scales in time and space. Currently, despite initially high development and deployment costs, sensors on board satellites offer arguably the most cost-effective long-term global monitoring capability, and recent developments have opened new possibilities for freshwater ecosystems. Earth observation platforms are now providing increasingly higher spatial and spectral resolution data that can be adapted to gain meaningful measurements as biological indicators of change, for instance aquatic vegetation coverage, phytoplankton functional types and water column chlorophyll-a concentration (Devred et al. 2013; Legleiter et al. 2014). Applications to lake ecosystems are widespread (Matthews et al. 2011), and global monitoring programmes are already being implemented, including Diversity II (www.diversity2.info) and Globolakes (Figure 3, www.globolakes.ac.uk) which, even in these early stages, already cover 340 and 971 lakes each, respectively. A promising avenue for freshwater ecosystem applications lies in hyperspectral technologies: the hundreds of narrow spectral bands provide more information on water column constituents such as phycocyanin, chlorophyll-a, suspended 
mater, phytoplankton functional types, and benthic composition (Devred et al., 2013). However, there are still high costs of transmitting, storing and manipulating these very large datasets, although the rapidly moving developments in infrastructure and computational capacity are likely to resolve these issues in the near future (Hestri et al. 2015), and several new hyperspectral global mapping programs are due to launch soon (e.g. HysplRI, https://hyspiri.jpl.nasa.gov and EnMap, http://www.enmap.org). Moreover, lightweight hyperspectral cameras on board small airborne devices, such as drones, open significant possibilities for monitoring key freshwater ecosystems such as headwater streams that are currently out of reach from satellites (Pajares et al. 2015, Lee et al. 2011).

Figure 3: Locations of 1000 lakes monitored by the Globaqua project using MERIS data between 2002 and 2012. Data covers 15 spectral bands across the globe every 3 days with $260 \times 300 \mathrm{~m}$ resolution. Indicators measured include physical variables such as temperature and turbidity, and biotic indicators such as chlorophyll-a.

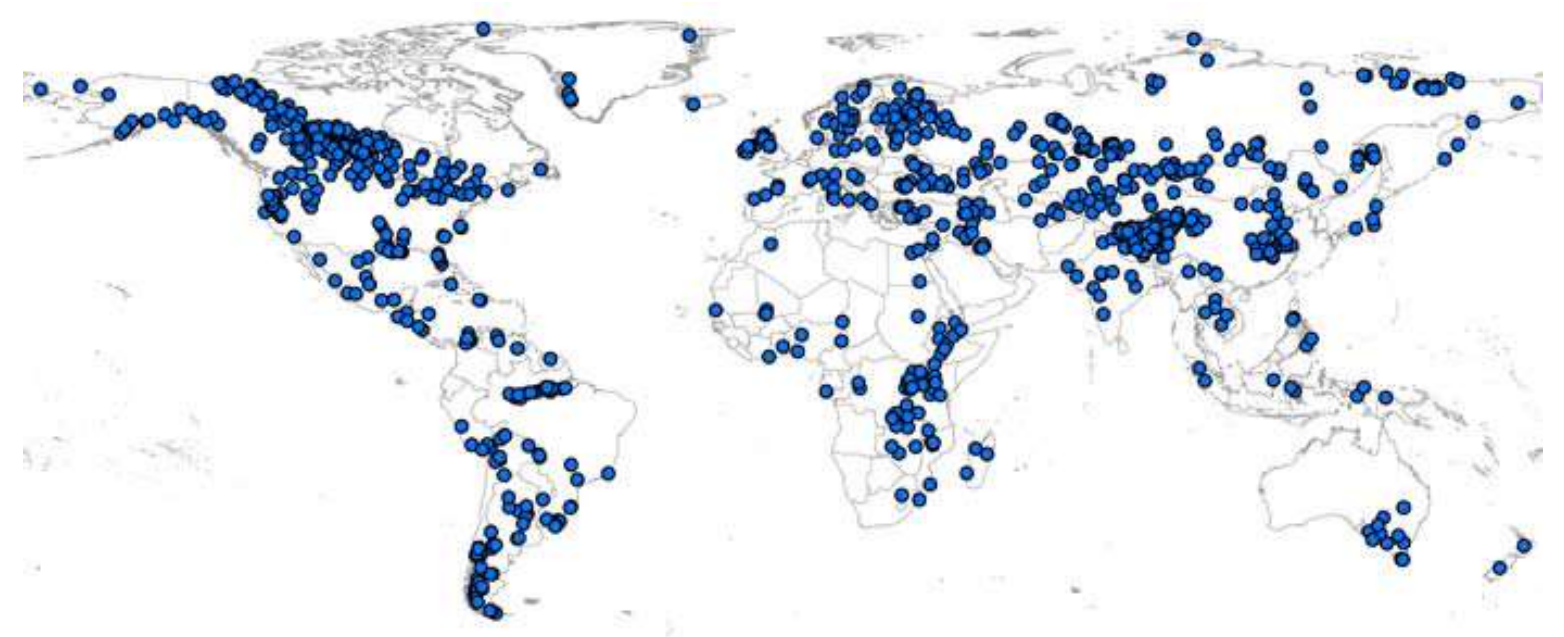


Remote sensing can also be used to evaluate past environmental stressors by using repositories of historical aerial imagery and maps that can be digitized and compared with more-recent images. For example, historical aerial photographs have been used to quantify the long-term geomorphic response of river channels to dam construction and water abstraction (e.g., Gurnell et. al 1994; Tiegs and Pohl 2005). Another option involves palaeo techniques, where hindcasting of past conditions and diversity is achieved by examining organisms preserved in lake sediment profiles (e.g. Smol and Cumming 2008). This approach could benefit from taxonomy-free DNA techniques to reconstruct past community responses to stressors, and evaluate ecosystem and diversity change through time. For example, ancient DNA (aDNA), an emerging tool which is used in a similar way to eDNA (Bohmann et al. 2014; Rawlence et al. 2014; Kidwell 2015), could be employed to identify long-term shifts in community structure due to past climate change or environmental perturbations.

\section{Conclusions and future directions}

From even our cursory "horizon scanning" overview presented here, it is clear that all of the indicators of ecosystem state suggested here are potentially relevant at a global scale, where currently there is a huge lack of standardised and suitable biological monitoring data. However, further research or development is needed to either synthesise regional methods (e.g. macroinvertebrate and fishery indices), expand global coverage (e.g. decomposition), or, in other cases to carry out additional cross-validation and quality control checks (e.g., molecular techniques, remote sensing). Given that many key environmental drivers of freshwater biodiversity and ecosystem processes and services are now available at a global scale with relatively fine resolution (e.g. Domisch et al., 2015), these data can be used to parametrize high-level models in order to extrapolate diversity to the complete landscapelevel. For example Kaelin \& Altermatt (2016) used a set of 39 environmental variables to 
predict diversity at different taxonomic resolution in $>20,000$ catchments, giving fine-scale insights into the spatial patterns of aquatic diversity across a vast area in ways that would have been inconceivable even just a few years ago.

We suggest that that these indices should be used with a high temporal consistency where methods are equivalent among years, so that diversity or ecosystem functioning measures collected today can be directly compared to those in the future. This consistency will be challenging to achieve as, for example, the methods for simple measurements of ambient temperatures have changed across the $19^{\text {th }}$ or $20^{\text {th }}$ century, and the emerging technologies of the $21^{\text {st }}$ century are developing at such a pace that the baselines are continually shifting, so a "lowest common denominator" needs to be established as soon as possible, while also having sufficient redundancy and scope to also enrich the information further in the future as the technology matures. Another challenge is that indices often only provide metrics which are loosely connected to ecosystem state and diversity (e.g. GLEON and remote sensing) or are in the early stages of development, so R\&D expenses are often still high (e.g. molecular techniques) and quality control/assurance is also relatively embryonic compared with the long-established but localised monitoring schemes that have already been in place in some parts of the world for many decades.

Furthermore, the future of freshwater diversity monitoring should also involve indicators to disentangle the multiple impacts of various co-occurring environmental stressors (Box 1). In particular, this is where new molecular tools and a focus on the huge functional and phylogenetic diversity contained within the members of the most neglected of freshwater taxa - those in the microbial "black box" - hold particular promise, as the potential number and scope of gene-to-ecosystem response variables is so vast that they are arguably the best placed as future bioindicators for disentangling multiple stressor effects at global scales (Jackson et al. 2016). In summary, we recommend that future monitoring in freshwaters 
should use a combination of the above molecular, remote sensing, and citizen science approaches to tackle the big issues facing our planet.

\section{Acknowledgments}

We are grateful to Future Earth, The Global Mountain Biodiversity Assessment and IPBES for the organisation of a workshop: 'Global Biodiversity Assessment and MonitoringScience, Data and Infrastructure Needs for IPBES and Beyond' in March 2016, where the idea for this paper was developed.

\section{References}

Allan, J.D., Abell, R., Hogan, Z.E.B., Revenga, C., Taylor, B.W., Welcomme, R.L., Winemiller, K., 2005. Overfishing of inland waters. BioScience. 55, 1041-1051.

Altermatt, F., Seymour, M., Martinez, N. 2013. River network properties shape $\alpha$-diversity and community similarity patterns of aquatic insect communities across major drainage basins. Journal of Biogeography. 40, 2249-2260.

Baird, D.J., Hajibabaei, M., 2012. Biomonitoring 2.0: a new paradigm in ecosystem assessment made possible by next-generation DNA sequencing. Molecular Ecology. 21, 2039-2044.

Bartley, D.M., De Graaf, G.J., Valbo-Jørgensen, J., Marmulla, G. 2015. Inland capture fisheries: status and data issues. Fisheries Management and Ecology. 22, 71-77.

Bellard, C., Bertelsmeier, C., Leadley, P., Thuiller, W., Courchamp, F. 2012. Impacts of climate change on the future of biodiversity. Ecology Letters. 15, 365-377. 
Boersma, K.S., Dee, L.E., Miller, S.J., Bogan, M.T., Lytle, D.A., Gitelman, A.I. 2016. Linking multidimensional functional diversity to quantitative methods: a graphical hypothesisevaluation framework. Ecology. 97, 583-593.

Bohmann, K., Evans, A., Gilbert, M.T.P., Carvalho, G.R., Creer, S., Knapp, M., Yu, D.W., de Bruyn, M. 2014. Environmental DNA for wildlife biology and biodiversity monitoring. Trends in Ecology and Evolution. 29, 358-367.

Brooks, E.G.E., Holland, R.A., Darwall, W.R.T., Eigenbrod, F. 2016. Global evidence of positive impacts of freshwater biodiversity on fishery yields. Global Ecology and Biogeography. Online first.

Brummett, R.E., Beveridge, M., Cowx, I.G., 2013. Functional aquatic ecosystems, inland fisheries and the Millennium Development Goals. Fish and Fisheries. 14, 312-324.

Beche L.A., McElravy E.P., Resh V.H. 2006. Long-term seasonal variation in the biological traits of benthic macroinvertebrates in two Mediterranean-climate streams in California, USA. Freshwater Biology. 51, 56-75.

Butchart, S.H., Walpole, M., Collen, B., Van Strien, A., Scharlemann, J.P., Almond, R.E., Baillie, J.E., Bomhard, B., Brown, C., Bruno, J., Carpenter, K.E. 2010. Global biodiversity: indicators of recent declines. Science. 328, 1164-1168.

Calizza, E., Costantini, M.L., Rossi, L., 2015. Effect of multiple disturbances on food web vulnerability to biodiversity loss in detritus-based systems. Ecosphere. 6, 1-20.

Charvet S., Statzner B., Usseglio-Polatera P., Dumont B. 2000. Traits of benthic macroinvertebrates in semi-natural French streams: an initial application to biomonitoring in Europe. Freshwater Biology. 43, 277-96.

Coll, M., Shannon, L.J., Kleisner, K.M., Juan-Jordá, M.J., Bundy, A., Akoglu, A.G., Banaru, D., Boldt, J.L., Borges, M.F., Cook, A., Diallo, I. 2016. Ecological indicators to capture the effects of fishing on biodiversity and conservation status of marine ecosystems. Ecological Indicators. 60, 947-962. 
Costello MJ., Claus S., Dekeyzer S., Vandepitte L., Tuama EO., Lear D., Tyler-Walters H. 2015. Biological and ecological traits of marine species. PeerJ, Doi 10.7717/peerj.1201

Crain C.M., Kroeker K., Halpern B.S. 2008. Interactive and cumulative effects of multiple human stressors in marine systems. Ecology Letters. 11, 1304-1315.

Crowl, T.A., McDowell, W.H., Covich, A.P., Johnson, S.L. 2001. Freshwater shrimp effects on detrital processing and nutrients in a tropical headwater stream. Ecology. 82, 775-783.

Deiner, K., Walser, J.C., Mächler, E., Altermatt, F. 2015 Choice of capture and extraction methods affect detection of freshwater biodiversity from environmental DNA. Biological Conservation. 183, 53-63.

Deiner, K., Altermatt, F. 2014. Transport Distance of Invertebrate Environmental DNA in a Natural River. PLoS ONE. 9, e88786

Demars, B.O.L., Kemp, J.L, Friberg, N., Usseglio-Polatera, P., Harper D.M. 2012. Linking biotopes to invertebrates in rivers: biological traits, taxonomic composition and diversity. Ecological Indicators. 23, 301-311.

Devred, E., Turpie, K., Moses, W., Klemas, V., Moisan, T., Babin, M., et al. 2013. Future retrievals of water column bio-optical properties using the hyperspectral infrared imager (HysplRI). Remote Sensing. 5, 6812-6837.

Dickens, C.W., Graham, P.M., 2002. The South African Scoring System (SASS) version 5 rapid bioassessment method for rivers. African Journal of Aquatic Science. 27, 1-10.

Doledec, S., Statzner, B., Bournard, M. 1999. Species traits for future biomonitoring across ecoregions: patterns along a human-impacted river. Freshwater Biology. 42, 737758. 
Domisch, S., Amatulli, G., Jetz, W. 2015. Near-global freshwater-specific environmental variables for biodiversity analyses in $1 \mathrm{~km}$ resolution. Scientific Data. 2, 150073.

Dudgeon, D., Arthington, A.H., Gessner, M.O., Kawabata, Z., Knowler, D.J., Lévêque, C., Naiman, R.J. et al. 2006. Freshwater biodiversity: importance, threats, status and conservation challenges. Biological reviews. 81, 163-182.

Durance, I., Bruford, M.W., Chalmers, R., Chappell, N.A., Christie, M., Cosby, B.J., Noble, D., Ormerod, S.J., Prosser, H., Weightman, A., Woodward, G. 2016. The challenges of linking ecosystem services to biodiversity: lessons from a large-scale freshwater study. Advances in Ecological Research. 54, 87-134.

FAO 2015. FishStat Plus: Universal software for fishery statistical time series. Data and Statistics Unit, FAO, Rome. http://www.fao.org/fishery/statistics/software/fishstat/en

Follett, R., Strezov, V. 2015. An Analysis of Citizen Science Based Research: Usage and Publication Patterns. PLoS ONE. 10, e0143687.

Friberg, N. Bonada, N., Bradley, D.C., Dunbar, M.J., Edwards, F.K., Grey, J. 2011. Biomonitoring of human impacts in freshwater ecosystems: the good, the bad and the ugly. Advances in Ecological Research. 44, 1-68

Garibaldi, L., 2012. The FAO global capture production database: a six-decade effort to catch the trend. Marine Policy. 36, 760-768.

Griffiths, N.A., Tiegs, S.D. 2016. Organic-matter decomposition along a temperature gradient in a forested headwater stream. Freshwater Science. 35, 518-533.

Global Biodiversity Outlook 4. 2014. A Mid-Term Assessment of Progress towards the Implementation of the Strategic Plan for Biodiversity 2011-2020. Secretariat of the CBD, Montréal, Canada. Available at https://www.cbd.int/gbo/gbo4/publication/gbo4en.pdf. 
Gray, C., Baird, D.J., Baumgartner, S., Jacob, U., Jenkins, G.B., O'Gorman, E.J., Lu, X., Ma, A., Pocock, M.J., Schuwirth, N., Thompson, M. 2014. FORUM: Ecological networks: the missing links in biomonitoring science. Journal of Applied Ecology. 51, 14441449.

Gurnell, A.M., Downward, S.R., Jones, R. 1994. Channel planform change on the River Dee meanders, 1876-1992. Regulated Rivers: Research and Management. 9, 187-204

Hestir, E., Brando, V.E., Bresciani, M., Giardino, C., Matta, E., Villa, P., Dekker, A. 2015. Measuring freshwater aquatic ecosystems: The need for a hyperspectral global mapping satellite mission. Remote Sensing of Environment. 167, 181-195.

Hladyz, S., Åbjörnsson, K, Giller, P.S., Woodward, G. 2011. Impacts of an aggressive riparian invader on community structure and ecosystem functioning in stream food webs. Journal of Applied Ecology. 48, 443-452.

Hoffmann, A., Penner, J., Vohland, K., Cramer, W., Doubleday, R., Henle, K., Kõljalg, U., Kühn, I., Kunin, W., Negro, J.J. and Penev, L., 2014. The need for an integrated biodiversity policy support process - Building the European contribution to a global Biodiversity Observation Network (EU BON). Nature Conservation. 6, 49.

Huddart, J.E., Thompson, M.S., Woodward, G. and Brooks, S.J., 2016. Citizen science: from detecting pollution to evaluating ecological restoration. Wiley Interdisciplinary Reviews: Water. 3, 287-300

Jackson, M.C., Loewen, C.J., Vinebrooke, R.D., Chimimba, C.T. 2016. Net effects of multiple stressors in freshwater ecosystems: a meta-analysis. Global change biology. 22, 180-189.

Jenkins, G.B., Woodward, G., Hildrew, A.G., 2016. Long-term amelioration of acidity accelerates decomposition in headwater streams. Global change biology 19, 11001106. 
Kaelin, K., Altermatt, F. 2016. Landscape-level predictions of diversity in river networks reveal opposing patterns for different groups of macroinvertebrates. Aquatic Ecology . In press.

Kelly, R.P., Port, J.A., Yamahara, K.M., Martone, R.G., Lowell, N., Thomsen, P.F., Mach, M.E., Bennett, M., Prahler, E., Caldwell, M.R., et al. 2014. Harnessing DNA to improve environmental management. Science. 344, 1455-1456.

Kidwell, S.M., 2015. Biology in the Anthropocene: Challenges and insights from young fossil records. Proceedings of the National Academy of Sciences. 112, 4922-4929.

Kokeš, J., Zahrádková, S., Němejcová, D., Hodovský, J., Jarkovský, J., Soldán, T. 2006. The PERLA system in the Czech Republic: a multivariate approach for assessing the ecological status of running waters. In The Ecological Status of European Rivers: Evaluation and Intercalibration of Assessment Methods (pp. 343-354). Springer Netherlands.

Lansdown, K., McKew, B.A., Whitby, C., Heppell C.M., Dumbrell A.J., Binley, A., Olde, L., Trimmer, M. 2016. Importance and controls of anaerobic ammonium oxidation influenced by riverbed geology. Nature Geoscience. 9, 357-360.

Lee B.S., McGwire K.C., Fritsen C.H. 2011. Identification and quantification of aquatic vegetation with hyperspectral remote sensing in western Nevada rivers, USA. International Journal of Remote Sensing. 32, 9093-9117.

Legleiter, C.J. 2014. Retrieving river attributes from remotely sensed data: an experimental evaluation based on field spectroscopy at the outdoor stream lab. River research and applications. 30, $671-684$.

Li, J., Nedwell, D.B., Beddow, J., Dumbrell, A.J., McKew, B.A., Thorpe, E.L., Whitby, C. 2015. amoA gene abundances and nitrification potential rates suggest that benthic ammonia-oxidizing bacteria $(\mathrm{AOB})$ not archaea $(\mathrm{AOA})$ dominate $\mathrm{N}$ cycling in the Colne estuary, UK. Applied and Environmental Microbiology. 81, 159-165. 
Lodge, D.M., Turner, C.R., Jerde, C.L., Barnes, M.A., Chadderton, L., Egan, S.P., Feder, J.L., Mahon, A.R., Pfrender, M.E. 2012. Conservation in a cup of water: estimating biodiversity and population abundance from environmental DNA. Molecular Ecology. $21,2555-2558$.

Mächler, E., Deiner, K., Spahn, F., Altermatt, F. 2016. Fishing in the Water: Effect of Sampled Water Volume on Environmental DNA-Based Detection of Macroinvertebrates. Environmental Science, Technology. 50, 305-312.

Matthews M.W. 2011. A current review of empirical procedures of remote sensing in inland and near-coastal transitional waters. International Journal of Remote Sensing. 32, $6855-6899$.

Mcgill BJ., Enquist BJ., Weiher E., Westoby M. 2006. Rebuilding community ecology from functional traits. Trends in Ecology and Evolution. 21, 178-185.

Menezes S., Baird D.J., Soares A. 2010. Beyond taxonomy: a review of macroinvertebrate trait-based community descriptors as tools for freshwater biomonitoring. Journal of Applied Ecology. 47, 711-719.

Nicholson, E., Collen, B., Barausse, A., Blanchard, J.L., Costelloe, B.T., Sullivan, K.M., Underwood, F.M., Burn, R.W., Fritz, S., Jones, J.P., McRae, L., 2012. Making robust policy decisions using global biodiversity indicators. PloS ONE. 7, e41128.

O'Gorman, E.J., Fitch, J.E., Crowe, T.P., 2012. Multiple anthropogenic stressors and the structural properties of food webs. Ecology. 93, 441-448.

Pajares, G. 2015. Overview and Current Status of Remote Sensing Applications Based on Unmanned Aerial Vehicles (UAVs). Photogrammetric Engineering and Remote Sensing. 81, 281-330.

Papaspyrou, S., Smith, C.J., Dong, L.F., Whitby, C., Dumbrell, A.J., Nedwell, D.B. 2014. Nitrate reduction functional genes and nitrate reduction potentials persist in deeper estuarine sediments. Why? PLoS ONE. 9, e94111. 
Pauly, D., Froese, R., 2012. Comments on FAO's State of Fisheries and Aquaculture, or 'SOFIA 2010'. Marine Policy. 36, 746-752.

Pereira, H.M., Ferrier, S., Walters, M., Geller, G.N., Jongman, R.H.G., Scholes, R.J., Bruford, M.W., Brummitt, N., Butchart, S.H.M., Cardoso, A.C., Coops, N.C. 2013. Essential biodiversity variables. Science. 339, 277-278.

Perkins, D.M., Bailey, R.A., Dossena, M., Gamfeldt, L., Reiss, J., Trimmer, M., Woodward, G. 2015. Higher biodiversity is required to sustain multiple ecosystem processes across temperature regimes. Global change biology. 21, 396-406.

Piggott, J.J., Salis, R.K., Lear, G., Townsend, C.R., Matthaei, C.D. 2015a. Climate warming and agricultural stressors interact to determine stream periphyton community composition. Global Change Biology. 21, 206-222.

Piggott, J.J., Townsend, C.R., Matthaei, C.D. 2015b. Reconceptualizing synergism and antagonism among multiple stressors. Ecology and Evolution. 5, 1538-1547.

Rabeni C.F., Doisy K.E., Zweig L.D. 2005. Stream invertebrate community functional responses to deposited sediment. Aquatic Sciences. 67, 395-402.

Raffaelli, D., Bullock, J.M., Cinderby, S., Durance, I., Emmett, B., Harris, J., Hicks, K., Oliver, T.H., Patersonk, D., White, P.C. 2014. Big data and ecosystem research programmes. Advances in Ecological Research. 51, 41-77.

Rawlence, N.J., Lowe, D.J., Wood, J.R., Young, J.M., Churchman, G., Huang, Y.T., Cooper, A. 2014. Using palaeoenvironmental DNA to reconstruct past environments: progress and prospects. Journal of Quaternary Science. 29, 610-626.

Rees, H.C., Maddison, B.C., Middleditch, D.J., Patmore, J.R., Gough, K.C. 2014. REVIEW: The detection of aquatic animal species using environmental DNA-a review of eDNA as a survey tool in ecology. Journal of Applied Ecology. 51, 1450-1459. 
Revenga, C., Campbell, I., Abell, R., De Villiers, P., Bryer, M. 2005. Prospects for monitoring freshwater ecosystems towards the 2010 targets. Philosophical Transactions of the Royal Society of London B: Biological Sciences. 360, 397-413.

QUINTESSENCE Consortium, 2016. Networking our way to better ecosystem service provision. Trends in ecology and evolution. Online first.

Salzburger, W., Mack, T., Verheyen, E., Meyer, A., 2005. Out of Tanganyika: genesis, explosive speciation, key-innovations and phylogeography of the haplochromine cichlid fishes. BMC Evolutionary Biology. 5, 17.

Scholes, R.J., Biggs, R. 2005. A biodiversity intactness index. Nature. 434, 45-49.

Seymour, M., Deiner, K., Altermatt, F. 2016. Scale and scope matter when explaining varying patterns of community diversity in riverine metacommunities. Basic and Applied Ecology. 17, 134-144.

Silvertown, J. 2016. "A new dawn for citizen science." Trends in ecology and evolution. 24, 467-471.

Smith, M.J., Kay, W.R., Edward, D.H.D., Papas, P.J., Richardson, K.S.J., Simpson, J.C., Pinder, A.M., Cale, D.J., Horwitz, P.H.J., Davis, J.A., Yung, F.H. 1999. AusRivAS: using macroinvertebrates to assess ecological condition of rivers in Western Australia. Freshwater Biology. 41, 269-282.

Smol, J,P., Cumming B.F. 2008. Tracking long-term changes in climate using algal indicators in lake sediments. Journal of Phycology. 36, 986-1011.

Stark, J.D. 1985. A Macroinvertebrates Community Index of Water Quality for Stony Streams. National Water and Soil Conservation Authority Wellington, Wellington, New Zealand. 
Statzner, B., Hoppenhaus, K., Arens, M.F., Richoux, P. 1997. Reproductive traits, habitat use and templet theory: a synthesis of world-wide data on aquatic insects. Freshwater Biology. 38, 109-135.

Sterk, M., Gort, G., Klimkowska, A., van Ruijven, J., van Teeffelen, A.J.A., Wamelink, G.W.W. 2013. Assess ecosystem resilience: Linking response and effects traits to environmental variability. Ecological Indicators. 30, 21-27.

Strayer, D.L., Dudgeon, D., 2010. Freshwater biodiversity conservation: recent progress and future challenges. Journal of the North American Benthological Society. 29, 344-358.

Stucki, P. 2010. Methoden zur Untersuchung und Beurteilung der Fliessgewässer: Makrozoobenthos Stufe F. Bundesamt für Umwelt, Bern. Umwelt-Vollzug. 1026, 61.

Taberlet, P., Coissac, E., Hajibabaei, M., Rieseberg, L.H. 2012 Environmental DNA. Molecular Ecology. 21, 1789-1793.

Tiegs, S.D., Clapcott, J.E., Griffiths, N.A., Boulton, A.J. 2013. A standardized cotton-strip assay for measuring organic-matter decomposition in streams. Ecological Indicators. 32, 131-139.

Tiegs, S.D., Pohl., M.M. 2005. Planform Channel Dynamics of the Lower Colorado River: 1976-1999. Geomorphology. 69, 14-27.

Tittensor, D.P., Walpole, M., Hill, S.L., Boyce, D.G., Britten, G.L., Burgess, N.D., Butchart, S.H., Leadley, P.W., Regan, E.C., Alkemade, R., Baumung, R., 2014. A mid-term analysis of progress toward international biodiversity targets. Science. 346, 241-244.

Thompson, M.S.A., Bankier, C., Bell, T., Dumbrell, A.J., Gray, C., Ledger, M.E., Lehmann, K., McKew, B.A., Sayer, C.D., Shelley, F., Trimmer, M., Warren, S.L., Woodward, G. 2016. Gene-to-ecosystem impacts of a catastrophic pesticide spill: testing a multilevel bioassessment approach in a river ecosystem. Freshwater Biology. Online first. 
Vacher, C., Tamaddoni-Nezhad, A., Kamenova, S., Peyrard, N., Moalic, Y., Sabbadin, R., Schwaller, L., Chiquet, J., Smith, M.A., Vallance, J., Fievet, V., Jakuschkin, B., Bohan, D.A. 2016. Chapter One-Learning Ecological Networks from Next-Generation Sequencing Data. Advances in Ecological Research. 54, 1-39.

Visco, J.A., Apothéloz-Perret-Gentil, L., Cordonier, A., Esling, P., Pillet, L., Pawlowski, J. 2015. Environmental Monitoring: Inferring the Diatom Index from Next-Generation Sequencing Data. Environmental Science, Technology. 49, 7597-7605.

Welcomme, R.L., 2011. An overview of global catch statistics for inland fish. ICES Journal of Marine Science: Journal du Conseil. fsr035.

Welcomme, R.L., Cowx, I.G., Coates, D., Béné, C., Funge-Smith, S., Halls, A. , Lorenzen, K., 2010. Inland capture fisheries. Philosophical Transactions of the Royal Society of London B: Biological Sciences. 365, 2881-2896.

Wright, J.F., Furse, M.T. and Moss, D., 1998. River classification using invertebrates: RIVPACS applications. Aquatic Conservation: Marine and Freshwater Ecosystems. 8, 617-631.

WWF. 2014. Living Plant Report 2014: Species and Spaces, People and Places (eds McLellan R, lyengar L, Jeffries B, Oerlemans N). World Wide Fund for Nature, Gland, Switzerland. 